\title{
Penerapan Kepemimpinan Asta Brata dalam Pendidikan dari Sudut Pandang Teori Konflik
}

\section{Wayan Aryawan ${ }^{1 *}$}

${ }^{1}$ Universitas Dwijendra, Indonesia

\author{
A R T I C L E I N F O \\ Article history: \\ Received 29 Januari 2021 \\ Accepted 17 Mei 2021 \\ Available online 30 Juni 2021 \\ Kata Kunci: \\ Kepemimpinan; Asta Brata; \\ Teori Konflik \\ Keywords: \\ Leadership; Asta Brata; \\ Conflict Theory
}

\begin{abstract}
A B S T R A K
Penelitian ini bertujuan untuk mengetahui penerapan kepemimpinan berlandaskan filosofi Asta Brata dalam pendidikan dari sudut pandang Teori Konflik. Metode yang digunakan dalam penelitian ini adalah metode kualitatif. Sumber data diperoleh melalui studi kepustakaan. Hasil penelitian ini yaitu filosofi Asta Brata merupakan filosofi yang menuntun seorang pemimpin memiliki sifat dari delapan dewa dalam agama Hindu yang terdiri dari Indra Brata, Yama Brata, Surya Brata, Candra Brata, Bayu Brata, Kuwera Brata, Baruna Brata, dan Agni Brata. Kepemimpinan Asta Brata dari sudut pandang teori konflik merupakan konsep kepemimpinan yang dapat digunakan sebagai peredam konflik. Pemimpin dalam hal ini kepala sekolah seharusnya memiliki sifat kedewataan sehingga dapat lebih bijaksana dalam menjalankan kepemimpinannya di lingkungan sekolah. Dengan sifat kedewataan yang diterapkan diharapkan konflik yang terjadi dapat dikelola menjadi konflik ke arah yang positif sehingga apa yang menjadi visi, misi dan tujuan sekolah dapat tercapai.
\end{abstract}

A B S T R A C T

This study aims to determine the application of leadership based on the Asta Brata philosophy in education from conflict theory. The method used in this research is the qualitative method. Data sources were obtained through literature studies. The result of this research is that the Asta Brata philosophy is a philosophy that guides a leader to have the characteristics of the eight gods in Hinduism, consisting of Indra Brata, Yama Brata, Surya Brata, Candra Brata, Bayu Brata, Kuwera Brata, Baruna Brata, and Agni Brata. Asta Brata's leadership from conflict theory is a leadership concept that can be used as a conflict reducer. In this case, the principal must have a mature character to be wiser in the performance of his leadership in the school environment. With the nature of maturity applied, it is expected that the conflict that arises can be handled into a conflict in a positive direction so that what is the vision, mission, and goals of the school can be achieved.

\footnotetext{
* Corresponding author.

E-mail addresses: aryawan@undwi.ac.id
} 



\section{Pendahuluan}

Pemimpin memegang peranan penting dalam suatu organisasi. Jika organisasi diibaratkan sebuah pesawat terbang maka pilot merupakan pemimpinnya. Tanpa memiliki kecakapan yang baik seorang pilot tidak akan dapat menerbangkan pesawatnya dengan baik. Begitu pula halnya dengan organisasi, tanpa pemimpin yang baik organisasi akan kehilangan arah dan menemui banyak kendala dalam pencapaian tujuannya.

Kepemimpinan adalah proses memengaruhi atau memberi contoh oleh pemimpin kepada pengikutnya dalam upaya mencapai tujuan organisasi. Pengaruh gaya kepemimpinan akan berdampak pada kinerja bawahan. Dalam memotivasi kinerja dari perusahaan atau organisasi sangat ditentukan oleh gaya kepemimpinan dari seorang pemimpin. Sedangkan kepemimpinan kepala sekolah merupakan suatu kemampuan dan kesiapan kepala sekolah untuk memengaruhi, membimbing, mengarahkan, dan menggerakkan staf sekolah agar dapat bekerja secara efektif dalam rangka mencapai tujuan pendidikan dan pengajaran yang telah ditetapkan, atau bisa dikatakan bantuan yang diberikan oleh kepala sekolah terhadap penetapan pencapaian tujuan pendidikan (Syamsul, 2017).

Tugas pokok seorang pemimpin menurut (Manik, 2013) yaitu: 1) Memberikan suatu kerangka pokok yang jelas yang dapat dijadikan pegangan bagi pengikut-pengikutnya; 2) Mengawasi, mengendalikan serta menyalurkan perilaku warga masyarakat yang dipimpinnya; 3) Bertindak sebagai wakil kelompok kepada dunia diluar kelompok yang dipimpin.

Di dalam organisasi, lembaga, maupun di lembaga pendidikan, kepala sekolah merupakan motor penggerak dan penentu arah kebijakan organisasi. Dalam sekolah/madrasah, kepala sekolah akan menentukan bagaimana tujuan-tujuan pendidikan dapat direalisasikan sehingga kepala sekolah dituntut senantiasa meningkatkan efektivitas kinerja dan memuaskan hasil kinerja lembaga (Syamsul, 2017).

Dalam filosofi kepemimpinan hindu dikenal konsep Asta Brata. Asta Brata adalah contoh kepemimpinan hindu yang terdapat dalam Itihasa Ramayana. Asta Brata yaitu delapan tipe kepemimpinan yang merupakan delapan sifat kemahakuasaan Tuhan. Pengertian Asta Brata adalah suatu ajaran, petunjuk atau nasehat kepemimpinan yang diberikan oleh Sri Rama kepada sang Wibisana pada waktu penobatannya menjadi Raja di Negeri Alengka Pura. Begitu juga Asta Brata ini merupakan wejangan-wejangan kepemimpinan yang diberikan oleh Sri Rama kepada adiknya Bharata pada waktu dinobatkan sebagai Raja Ayodhya Pura untuk menggantikan kedudukan Sri Rama karena pembuangannya di hutan selama 12 tahun (Sudarmiati, 2020).

Asta Brata yang telah dilaksanakan oleh Sri Kresna, Yudhistira, Empu Kuturan (di Bali waktu beliau dipercaya sebagai Bhagawanta atau penasehat Raja) begitu juga oleh Sri Rama, mengandung definisi sebagai delapan sikap mental yang harus dimiliki oleh seorang pemimpin, yaitu Indra Brata, Yama Brata, Surya Brata, Candra Brata, Bayu Brata, Kuwera Brata, Baruna Brata, dan Agni Brata (Sidharta, 2010).

Kepemimpinan merupakan suatu proses sosial yang dilakukan oleh seseorang atau lembaga yang meliputi segala tindakan yang dilakukannya dapat menyebabkan gerak dari warganya atau bawahannya. Dalam proses kepemimpinan yang diharapkan seorang pemimpin yaitu bawahannya mau mengikuti/menjalankan apa yang telah ditugaskan untuk mencapai tujuan organisasi. Hanya saja proses kepemimpinan dalam organisasi tidak semuanya berjalan lancar. Biasanya ada saja perbedaan pendapat atau ketidaksepahaman antara pimpinan dengan bawahannya sehingga memicu terjadinya konflik.

Konflik secara etimologis adalah pertengkaran, perkelahian, perselisihan tentang pendapat atau keinginan; atau perbedaan; pertentangan berlawanan dengan; atau berselisih dengan. Dalam Kamus Besar Bahasa Indonesia (KBBI) konflik mempunyai arti percekcokan; perselisiah; dan pertentangan. Sedangkan menurut kamus sosiologi konflik bermakna the overt struggle between inthviduals or groups within a society, or between nation states, yakni pertentangan secara terbuka antara individu-individu atau kelompok-kelompok di dalam masyarakat atau antara bangsabangsa (Tualeka, 2017).

Sumber-sumber konflik dapat dibagi menjadi lima (Brata, 2011), yaitu: 1) Biososial, pakar manajemen menempatkan frustasi-agresi sebagai sumber konflik. Berdasarkan pendekatan ini, 
frustasi sering menghasilkan agresi yang mengarah pada terjadinya konflik; 2) Kepribadian dan Interaksi, termasuk di dalamnya adalah kepribadian yang abrasive (suka menghasut), gangguan psikologi, kemiskinan, keterampilan interpersional, kejengkelan, persaingan (rivalitas), perbedaan gaya interaksi, ketidaksederajatan hubungan; 3) Struktural, konflik yang melekat pada struktur organisasi dan masyarakat seperti yang disulut oleh kekuasaan, status, dan kelas sosial; 4) Budaya dan Ideologi, intensitas konflik dari sumber ini sering dihasilkan dari perbedaan politik, sosial, agama, dan budaya; dan 5) Konvergensi (gabungan), dalam situasi tertentu sumbersumber konflik itu menjadi satu, sehingga menimbulkan kompleksitas konflik itu sendiri.

Teori konflik adalah teori yang memandang bahwa perubahan sosial tidak terjadi melalui proses penyesuaian nilai-nilai yang membawa perubahan, tetapi terjadi akibat adanya konflik yang menghasilkan kompromi-kompromi yang berbeda dengan kondisi semula (Tualeka, 2017). teori konflik adalah beberapa teori atau sekumpulan teori yang menjelaskan tentang peranan konflik, terutama antara kelompok-kelompok dan kelas-kelas dalam kehidupan sosial masyarakat.

Teori sosiologi fungsionalisme struktural menyebutkan keteraturan akan terjadi dalam organisasi jika anggota organisasi dapat bekerja secara bersama-sama dalam suatu cara yang relatif teratur menurut seperangkat aturan atau nilai yang telah ditetapkan, maka dalam hal ini jika dikaitkan dengan kepemimpinan, pemimpin dianggap berhasil dalam memimpin bawahannya karena dapat mewujudkan stabilitas dan keseimbangan dalam mencapai tujuan organisasi. Dari sudut pandang teori konflik yang merupakan antitesis dari teori fungsionalisme struktural, organisasi senantiasa berada dalam proses perubahan yang ditandai oleh pertentangan yang terus-menerus diantara unsur-unsur organisasi. Keteraturan yang terdapat dalam organisasi hanyalah disebabkan karena adanya tekanan atau pemaksaan kekuasaan dari atas oleh penguasa/pimpinan. Distribusi kekuasaan dan wewenang secara tidak merata tanpa kecuali menjadi faktor yang menentukan konflik sosial secara sistematis. Konflik dapat memberikan dampak negatif maupun dampak positif dalam organisasi. Oleh karena itulah peran kepemimpinan sangat penting untuk dapat membawa konflik ke arah positif dengan harapan tujuan-tujuan organisasi dapat lebih cepat tercapai (Komara, 2019).

Permasalahan kepemimpinan yang sering terjadi di sekolah yaitu tidak semua kepala sekolah mempunyai kemampuan yang sama dalam mengelola konflik yang terjadi. Baik konflik antara kepala sekolah dengan bawahannya atau konflik yang terjadi sesama guru ataupun pegawai/tenaga kependidikan, bahkan tidak menutup kemungkinan konflik yang terjadi pada siswa dan pihak eksternal lainnya. Kurangnya kemampuan mengelola konflik ini akan mengakibatkan dampak negatif yang menyebabkan munculnya permasalah lain seperti penurunan motivasi kerja dan kinerja sekolah yang akan menghambat kemajuan sekolah. Oleh karena itu, ajaran Asta Brata sebagai salah satu filosofi kepemimpinan Hindu dapat digunakan sebagai pedoman dalam menjalankan kepemimpinan di sekolah untuk membawa konflik yang terjadi kearah kemajuan sekolah.

Dalam penerapan kepemimpinan Asta Brata tersebut tentu saja konflik-konflik tetap akan terjadi. Dari sudut pandang teori konflik, konflik-konflik atau ketegangan-ketegangan yang terjadi merupakan hal yang diperlukan agar tercipta perubahan-perubahan sosial. Oleh karena itu, dengan pemahaman terhadap teori konflik diharapkan perubahan sosial yang terjadi adalah perubahan yang positif sehingga dapat mempercepat pencapaian tujuan organisasi, bukan malah menjatuhkan organisasi, sehingga pemahaman teori konflik oleh seorang kepala sekolah sangat diperlukan dalam mengelola konflik yang ada di sekolah. Di dalam konflik, selalu ada negosiasinegosiasi yang dilakukan sehingga terciptalah suatu konsensus (Diharjo, 2019).

Sehubungan dengan hal tersebut, penelitian ini mencoba mengkaji dan memberi gambaran bagaimana penerapan kepemimpinan yang berlandaskan filosofi kearifan lokal Asta Brata jika dilihat dari sudut pandang teori konflik. 


\section{Metode}

Metode yang digunakan dalam penulisan penelitian ini adalah metode kualitatif, yang lebih menekankan kepada pemaparan dengan tujuan untuk memperoleh gambaran (deskripsi) lengkap tentang keadaan tertentu, pada suatu tempat tertentu dan pada saat tertentu. Sumber data dan pengumpulan data dilakukan melalui studi kepustakaan, yaitu mendapatkan data melalui bahan-bahan kepustakaan yang dilakukan dengan cara membaca dan menelaah bukubuku literatur tentang manajemen pendidikan dan teori sosiologi, serta jurnal-jurnal ilmiah tentang kepemimpinan, konsep Asta Brata, teori konflik dan manajemen konflik. Untuk memperkuat studi kepustakaan ini buku-buku dan jurnal-jurnal ilmiah yang digunakan dipilih terbitan maksimal sepuluh tahun terakhir. Dalam mengkaji penerapan kepemimpinan Asta Brata terkait konflik yang ada di lingkungan sekolah maka digunakan pendekatan kontekstual. Pendekatan ini akan menghubungkan konsep kepemimpinan Asta Brata dengan contoh nyata konflik yang terjadi di lingkup sekolah.

Tahapan analisis data dilakukan menggunakan teknik analisis model Miles dan Huberman yaitu mengadakan kegiatan reduksi data, penyajian data, serta penarikan kesimpulan/verifikasi data (Sugiyono, 2019). Tahap reduksi data merupakan suatu bentuk analisis yang menajamkan, menggolongkan, mengarahkan, membuang yang tidak perlu, dan mengorganisasi data dengan cara sedemikian rupa hingga kesimpulan-kesimpulan finalnya dapat ditarik dan diverifikasi. Hasil reduksi data dalam penelitian ini kemudian disajikan dalam bentuk deskripsi-deskripsi yang mengerucut kepada pemecahan masalah yang akan dibahas. Tahap terakhir dari analisis adalah penarikan kesimpulan. Kesimpulan yang muncul dari data yang disajikan kemudian diuji kebenarannya, kekokohannya, dan kecocokannya, yakni yang merupakan validitasnya. Pengujian kesimpulan akhir yang ditemukan diverifikasi kembali dengan sumber-sumber literatur yang digunakan agar benar-benar dapat dipertanggungjawabkan.

\section{Hasil dan Pembahasan}

Ajaran Asta Brata dapat dilihat dari contoh yang telah ada. Salah satu pemimpin yang telah melakukannya adalah Sri Rama dalam cerita dan Kekawin Ramayana. Dimana pada Kekawin Ramayana, Sri Rama memberikan wejangan tentang ajaran-ajaran Asta Brata kepada Wibisana yang hendak memimpin Alengka untuk menggantikan kakaknya Rahwana yang telah gugur dalam medan perang.

Untuk menjadi seorang pemimpin yang baik, pemimpin haruslah selalu memiliki wiweka (sikap berhati-hati) terhadap segala tingkah lakunya serta terhadap keputusan yang diambilnya. Karena rakyat yang dipimpinnya (bawahannya) akan mengikuti segala contoh perbuatan yang dilakukan oleh pemimpinnya. Sehingga seorang pemimpin lengah sedikit saja, maka akan dapat mengakibatkan kehancuran bagi rakyatnya.

Pemimpin akan dihormati oleh rakyatnya, tidak ada yang akan berani melawannya serta tidak ada yang akan mampu menyaingi wibawanya. Karena dipercaya bahwa seseorang dapat menjadi pemimpin karena terdapat kekuatan Dewa yang ada pada dirinya. Dan juga terdapat delapan Dewa yang merupakan manifestasi dari Tuhan yang bersemayam pada dirinya. Para pemimpin seharusnya mampu membangun kepercayaan rakyat terhadapanya serta selalu menjunjung dharma (kebenaran) dalam kepemimpinanya. Hal ini dapat terwujud jika pemimpin itu sendiri dapat menerapkan ajaran-ajaran yang terdapat pada Asta Brata dengan baik dan benar.

Untuk menyeimbangkan suatu sistem kepemimpinan, seorang pemimpin haruslah memiliki acuan segala tindakannya untuk menciptakan kemakmuran dan kesejahteraan rakyat yang dipimpinnya maupun bagi dirinya sendiri. Asta Brata yang terdiri dari sifat-sifat partikel yang kekal dari Dewa Indra, Bayu, Yama, Surya, Agni, Baruna, Candra, dan Kuwera, mengandung berbagai ajaran yang sangat berpengaruh dan menentukan berhasil tidak jalannya suatu pemerintahan. Adapun ajaran Asta Brata terdapat pada bagian-bagiannya (Sudarmiati, 2020) yaitu sebagai berikut: 
1) Indra Brata

Indra Brata, yaitu cara kepemimpinan yang mengikuti sifat Dewa Indra sebagai Dewa hujan. Dalam hubungan ini hendaknya para pemimpin seperti air yang berasal dari bawah terus menguap dan turun kembali menjadi hujan untuk memberi hidup semua makhluk di dunia ini. Makna yang terkandung dari pernyataan ini ialah bahwa seorang pemimpin hendaknya jangan lupa pada rakyat yang di pimpinnya. Hendaklah mereka selalu memperjuangkan rakyat untuk bebas dari penderitaan dan bahagia lahir batin. Seorang pemimpin hendaklah mengikuti ajaran Indra Brata, karena Indra Brata memberikan ketauladan sifat yang baik seorang pemimpin untuk dapat memberikan bimbingan kepada masyarakat, bawahannya serta untuk dirinya agar selalu berusaha menciptakan kemakmuran dan kesejahteraan.

2) Yama Brata

Yama Brata, yaitu para pemimpin hendaknya mengikuti sifat-sifat Dewa Yama. Dalam hubungan ini para pemimpin diharapkan menegakkan hukum secara benar dan adil, yang bersalah menurut hukum, harus dihukum dan yang tidak bersalah harus dilindungi. Hendaklah para pemimpin tidak memiliki sifat pilih kasih dalam menegakkan hukum, karena hal itu akan dapat merugikan masyarakat dan Negara yang dipimpinnya.

Dalam menegakkan hukum kepada rakyat yang bersalah hendaknya para pemimpin harus tegas dan konsekuen serta tidak memandang status maupun kedudukan sosial. Sehingga ketertiban dan keamanan di masyarakat dapat ditegakkan. Ajaran Yama Brata ini juga diharapkan agar pemimpin mengajak seluruh rakyatnya untuk selalu mematuhi hukum yang berlaku sehingga ketertiban dan keamanan dapat terlaksana dengan baik.

\section{3) Surya Brata}

Surya Brata, yaitu para pemimpin hendaknya mampu memberikan penerangan secara benar, adil dan merata kepada seluruh warga negaranya. Dalam hubungan ini pula hendaknya para pemimpin selalu berhati-hati dalam mengeluarkan keputusan, seperti layaknya matahari yang sangat berhati-hati dalam menyerap air yang ada di muka bumi ini. Pemimpin hendaknya pula dapat meniru prilaku matahari yang terus bekerja setiap hari yang selalu menerangi jagad raya walaupun gumpalan embun mengalangi sinarnya, matahari selalu terbit dengan berjalan dari timur ke arah barat menuju peraduannya. Matahari pun tidak pernah mengharapkan balasan akan kerja kerasnya (tanpa keterikatan). Adapun penerangan yang dimaksud dalam hal ini yaitu, pemimpin hendaknya selalu memberikan informasi yang benar kepada rakyatnya mengenai jalannya kepemimpinan yang di pimpinnya tanpa menutupi hal apapun. Pemimpin juga berkewajiban untuk meningkatkan taraf hidup rakyatnya.

\section{4) Candra Brata}

Candra Brata yaitu para pemimpin hendaknya selalu dapat memperlihatkan wajah yang tenang dan berseri-seri dalam tugasnya sehari-hari, sehingga dengan demikian rakyat yang dipimpinnya merasa yakin akan kebesaran jiwa pemimpinnya serta simpati dan penuh rasa hormat.

Disamping itu juga, para pemimpin hendaknya dapat menyebarkan keindahan dan berusaha memberikan kebahagiaan kepada setiap orang dengan jalan memberantas segala hal-hal negatif yang menyelimuti jiwanya. Seperti bulan yang berlahan-lahan membebaskan diri dari kabut malam yang menyelimutinya. Pemimpin juga diharapkan dapat menyejukan rakyat (peneduh) laksana bulan, maksudnya yaitu menampung segala aspirasi yang diberikan oleh rakyat dan bawahannya. Apalagi pendapat yang diberikan oleh rakyat merupakan hal yang positif, untuk kelancaran jalannya kepemimpinan yang sedang berlangsung.

\section{5) Bayu Brata}

Bayu Brata yaitu para pemimpin hendaknya selalu mengetahui keadaan dan kemauan rakyat yang paling bawah dan menderita. Dalam hubungan ini dilukiskan para pemimpin sebagai Dewa Angin atau Dewa Bayu yang selalu berhembus dari daerah yang bertekanan tinggi ke daerah yang bertekanan rendah. Para pemimpin hendaknya selalu berada di tengah-tengah 
masyarakat yang dipimpinnya untuk memantau kehidupan rakyatnya. Untuk keadaan dan kehendak rakyatnya, hendaknya pemimpin dapat menampakkan senyum dan sapa yang manis serta dapat mengetahui motif kesenangan masyarakat sehingga mudah menyelami jiwanya.

Dalam Bayu Brata juga diajarkan agar para pemimpin memiliki daya adaptasi yang tinggi, merakyat dan memiliki rasa ingin tahu yang tinggi tentang semua rakyatnya. Sehingga para pemimpin tidak terkesan sebagai orang yang gila akan kedudukan dimana jika sudah berada di tempat yang tinggi maka akan enggan untuk berkunjung kebawah lagi. Adapun maksud dari pada pemimpin harus mempunyai daya adaptasi yang tinggi yaitu ketika menjalankan tugasnya dari suatu daerah ke daerah lain yang menjadi wilayah kekuasaannya, hendaknya para pemimpin yang baik tanpa harus membanding-bandingkan daerah yang satu dengan daerah yang lain serta dapat berkomunikasi dengan orang-orang setempat tanpa rasa canggung.

6) Kuwera Brata

Kuwera Brata yaitu para pemimpin hendaknya memiliki sifat-sifat bijaksana dalam mempergunakan dana, sehingga pembangunan masyarakat yang adil dan makmur dapat terwujud sebagaimana mestinya. Para pemimpin hendaknya mampu mempergunakan uang sehemat mungkin, tanpa ada pemborosan, sehingga dengan demikian semua rencana dapat terwujud. Selain hal tersebut, pemimpin hendaknya pandai dalam menggali potensi wilayah yang dipimpinnya sehingga dapat menghasilkan dana untuk kelangsungan dan kemakmuran hidup rakyat yang dipimpinnya. Hal ini sangatlah penting, apalagi seperti zaman sekarang dimana teknologi sudah maju pesat. Berbagai zat yang terdapat di alam dapat dimanfaatkan untuk menghasilkan dana yang diperlukan dalam segala bidang pembangunan. Namun, disamping itu para pemimpin tidak boleh lupa untuk melestarikan kembali apa yang telah diambilnya dari alam sehingga tercipta suatu keseimbangan diantara kehidupan manusia dengan alamnya. Yang mana jika hal tersebut terwujud maka akan tercipta kehidupan masyarakat yang makmur dengan di dampingi oleh alam yang bersahabat.

\section{7) Baruna Brata}

Baruna Brata yaitu para pemimpin hendaknya memiliki wawasan yang luas, dan sanggup mengatasi setiap gejolak dengan penuh kearifan. Para pemimpin hendaknya mampu mengatasi berbagai macam hambatan seperti kekacauan ekonomi, politik, pengangguran, demo dan sejenisnya. Pemimpin hendaknya pula pandai mencari solusi terhadap berbagai masalah yang terjadi di masyarakatnya, dengan dibantu oleh para pendampingnya (para menteri) sehingga masalah tersebut cepat terselesaikan. Merupakan suatu kewajiban bagi pemimpin untuk memiliki beberapa menteri untuk memberikannya nasehat dalam menyelesaikan berbagai masalah kepemimpinan untuk kebahagian serta kemakmuran rakyatnya.

8) Agni Brata

Agni Brata yaitu para pemimpin hendaknya memiliki sifat pemberani dan memiliki dedikasi yang tinggi dalam mengatasi suatu masalah yang menimpa masyarakatnya. Diibaratkan sebagai Dewa Agni (Api) yang tidak pernah berhenti membakar benda yang dibakar sehingga menjadi abu.

Para pemimpin juga diharapkan agar meniru sifat api yang selalu berkobar meskipun berbagai rintangan menghadangnya. Adapun maksudnya yaitu, hendaknya pemimpin memiliki semangat yang berkobar-kobar seperti api dan tidak pernah putus asa dalam menyelesaikan semua perkara yang terjadi dalam kepemimpinannya. Agni Brata juga mengajarkan agar sebelum mengambil keputusan penting yang menyangkut kemakmuran rakyatnya, seorang pemimpin haruslah terlebih dahulu menyucikan dirinya.

Demikianlah ajaran-ajaran yang terdapat pada bagian-bagian Asta Brata yang hendaknya ditiru dan dilaksanakan oleh para pemimpin. Sehingga dengan adanya ajaran-ajaran Asta Brata ini, diharapakan para pemimpin lebih bijaksana dalam segala hal yang berhubungan dengan hajat hidup orang banyak. 
Teori konflik atau teori struktural konflik mulai diperkenalkan pada tahu 1960 -an. Pertama kali, teori ini muncul dalam sosiologi Amerika Serikat sebagai kebangkitan kembali dari berbagai gagasan yang diungkapkan sebelumnya oleh Karl Marx dan Max Weber. Jadi, ide dasar dari teori konflik ini diambil dari pemikiran kedua pemikir ini. Marx dan Weber secara tegas menolak gagasan yang menyatakan bahwa masyarakat cenderung mengarah pada konsensus dasar atau harmoni, dimana struktur masyarakat yang berlangsung bekerja untuk kebaikan setiap orang. Padahal, konflik dan pertentangan kepentingan masing -masing individu dan kelompok menurut Marx dan Weber adalah saling bertentangan, dan merupakan determinan utama dalam pengorganisasian kehidupan sosial.

Teori konflik berpendapat bahwa kehidupan sosial di masyarakat terdapat berbagai bentuk pertentangan. Paksaan dalam wujud hukum dipandang sebagai faktor utama untuk memelihara lembaga-lembaga sosial, seperti milik pribadi (property), perbudakan (slavery), kapital yang menimbulkan ketidaksamaan hak kesamaan. Kesenjangan sosial terjadi dalam masyarakat karena bekerjanya lembaga paksaan tersebut yang bertumpu pada cara-cara kekerasan, penipuan dan penindasan. Dengan demikian, titik tumpu dari konflik sosial adalah kesenjangan sosial (Maunah, 2015).

Konflik memiliki perspektif yang berbeda dengan perspektif fungsional karena melihat kontribusi yang positif kepada lembaga pendidikan dalam masyarakat. Dalam perspektif ini terdapat penekanan-penekanan adanya perbedaan yang sangat menyolok yang ada pada setiap diri individu dalam mendukung suatu sistem sosial. Konflik menunjukkan adanya perbedaan pada masing-masing individu disebabkan karena mempunyai kebutuhan yang sangat terbatas. Adapun kemampuan untuk memenuhi kebutuhan individu tersebut saling berbeda satu dengan yang lainya.

Teori konflik berpandangan perubahan sosial terjadi melalui proses penyesuaian nilai-nilai yang berdampak pada perubahan dan menghasilkan kompromi-kompromi yang berbeda dengan kondisi semula. Proses konflik bersifat instrumental dalam penyatuan, pemeliharaan dan pembentukan dalam struktur sosial.

Adapun hal-hal yang menyebabkan munculnya konflik antara lain: 1) Konflik diri sendiri dengan seseorang dapat terjadi karena perbedaan peranan, kepribadian dan kebutuhan. 2) Konflik diri sendiri dengan kelompok dapat terjadi karena individu tersebut mendapat tekanan, atau individu bersangkutan telah melanggar norma-norma kelompok sehingga dimusuhi atau dikucilkan oleh kelompoknya. 3) Konflik terjadi karena adanya suatu ambisi salah satu kelompok untuk berkuasa (Usman, 2013).

Dari cara menghadapi dan menyelesaikan konflik sosial dapat diklasifikasikan: 1) Konflik kalah versus kalah. Dalam sebuah konflik pasti terdapat pihak-pihak yang saling berselisih dan melakukan aksi saling mengalahkan, menyingkirkan atau melenyapkan. Dalam hal ini masingmasing pihak saling kalah, jadi berakhir saling kalahnya kedua pihak. 2) Konflik kalah versus menang. Konflik akan berakhir dalam bentuk kalah versus menang apabila salah satu pihak yang bertikai mencapai keinginanya dengan mengorbankan keinginan pihak lain. 3) Konflik menang versus menang. Konflik akan berakhir menang versus menang jika pihak-pihak yang berkaitan bersedia satu sama lain untuk mencapai kesepakatan baru yang saling menguntungkan (Usman, 2013).

Beberapa cara untuk mengatasi konflik menurut Nader and Todd, dalam salah satu bukunya, The Disputing Process Law In Ten Societies (Brata, 2011), yaitu : 1) Bersabar (Lumping), yaitu suatu tindakan yang merujuk pada sikap yang mengabaikan konflik begitu saja atau dengan kata lain isu- isu dalam konflik itu mudah untuk diabaikan, meskipun hubungan dengan orang yang berkonflik itu berlanjut, karena orang yang berkonflik kekurangan informasi atau akses hukumnya tidak kuat; 2) Penghindaran (Avoidance), yaitu suatu tindakan yang dilakukan untuk mengakhiri hubungannya dengan cara meninggalkan konflik, didasarkan pada perhitungan bahwa konflik yang terjadi atau dibuat tidak memiliki kekuatan secara sosial, ekonomi dan emosional; 3) Kekerasan atau paksaan (Coercion), yaitu suatu tindakan yang diambil dalam mengataasi konflik jika dipandang bahwa dampak yang ditimbulkan membahayakan; 4) Negosiasi (Negotation) ialah tindakan yang menyangkut pandangan bahwa penyelesaian konflik dapat dilakukan oleh orang- orang yang berkonflik secara bersama-sama tanpa melibatkan pihak 
ketiga. Kelompok tidak mencari pencapaian solusi dan term satu aturan, tetapi membuat aturan yang dapat mengorganisasikan hubungannya dengan pihak lain; 5) Konsiliasi (Conciliation), yaitu tindakan untuk membawa semua yang berkonflik kemeja perundingan. Konsiliator tidak perlu memainkan secara aktif satu bagian dari tahap negosiasi meskipun ia mungkin bisa melakukannya dalam batas diminta oleh yang berkonflik. Konsiliator sering menawarkan konstektual bagi adanya negosiasi dan bertindak sebagai penengah. 6) Mediasi (Mediation), hal ini menyangkut pihak ketiga yang menangani/ membantu menyelesaikan konflik agar tercapai persetujuan. 7) Arbritasi (Arbritation), kedua belah pihak yang berkonflik setuju pada keterlibatan pihak ketiga yang memiliki otoritas hukum dan mereka sebelumnya harus setuju untuk menerima keputusannya; 8) Peradilan (Adjudication), hal ini merujuk pada intervensi pihak ketiga yang berwenang untuk campur tangan dalam penyelesaian konflik, apakah pihak- pihak yang berkonfllik itu menginginkan atau tidak.

Pendekatan berikut ini dapat digunakan sebagai kontribusi peran kepemimpinan dalam mengendalikan/menyelesaikan konflik: 1) Sanggup menyampaikan pokok masalah penyebab timbulnya konflik. Konflik tidak dapat diselesaikan jika permasalahan pokoknya terisolasi. Konflik sangat tergantung pada konteks dan setiap pihak yang terkait seharusnya memahami konteks tersebut. Permasalahan menjadi jelas tidak berdasarkan asumsi, melainkan jika disampaikan dalam pernyataan pasti; 2) Pendekatan dengan adanya konfrontasi dalam menyelesaikan konflik biasanya justru mengarahkan orang untuk membentuk kubu. Untuk itu , bicarakan pokok permasalahan, bukan siapa yang jadi penyebabnya; 3) Bersedia melatih diri untuk mendengarkan dan mempelajari perbedaan. Pada umumnya kemauan mendengarkan sesuatu dibarengi dengan keinginan untuk memberi tanggapan. Seharusnya kedua belah pihak berusaha untuk benar-benar saling mendengarkan; 4) Sanggup mengajukan usul atau nasehat. Ajukan usul baru yang disadari oleh tujuan kedua belah pihak dan dapat mengakomodasikan keduanya. Tawarkan juga kesediaan untuk selalu dapat membantu perwujudan rencana- rencana tersebut; 5) Meminimalisasi ketidakcocokan. Cari jalan tengah diantara kedua belah pihak yang sering berbeda pandangan dan pendapat. Fokuslah pada persamaan dengan mempertimbangkan perbedaan yang sifatnya tidak mendasar (Brata, 2011).

Teori konflik juga tak luput dari kelemahan. Beberapa kritik yang ditujukan pada teori konflik, meliputi: 1) Teori konflik dianggap mengabaikan ketertiban dan stabilitas dalam masyarakat. Padahal, sekalipun konflik-konflik dan perubahan adalah bagian dari masyarakat, tapi bukan berarti masyarakat tidak pernah mengalami kondisi dengan ketertiban dan stabilitas; 2) Teori konflik memiliki dasar ideologi radikal. Sama halnya dengan fungsionalisme yang dikritik karena ideologi konservatifnya, kedua teori ini dianggap tidak cukup memadai dalam menganalisa kehidupan sosial masyarakat karena masing-masing hanya dapat menerangkan sebagian kehidupan sosial saja. Padahal, diperlukan perspektif teoritis yang mampu menerangkan konflik dan ketertiban sekaligus.

Ajaran Asta Brata pada prinsipnya merupakan proses dewataisasi yaitu menjadikan seorang pemimpin memiliki sifat-sifat kedewaan sehingga rakyat yang dipimpinnya menjadi bahagia dan sejahtera. Konsep kepemimpinan Asta Brata merupakan filosofi kepemimpinan hindu dimana seorang pemimpin diibaratkan mempunyai kekuatan delapan Dewa yang merupakan manifestasi dari Tuhan yang bersemayam pada dirinya. Ajaran ini tentunya menuntun seorang pemimpin untuk menuju keharmonisan bagi masyarakat atau organisasi yang dipimpinnya.

Pada kenyataannya tidak semua upaya atau usaha yang dilakukan seorang pemimpin dapat berjalan lancar, pasti saja dalam perjalanannya seorang pemimpin menemui konflik baik konflik pribadi, antar pribadi maupun konflik anggota pada organisasi yang dipimpinnya atau bisa saja terjadi konflik eksternal organisasi.

Dari sudut pandang teori konflik, konflik akan terjadi apabila ada perbedaan pemahaman antara dua orang atau lebih terhadap berbagai perselisihan, ketegangan, kesulitan-kesulitan diantara para pihak yang tidak sepaham. Konflik juga bisa memicu adanya sikap berseberangan (oposisi) antara kedua belah pihak dimana masing-masing pihak memandang satu sama lainnya sebagai lawan/penghalang dan diyakini akan mengganggu upaya tercapainya tujuan dan tercukupinya kebutuhan masing-masing. 
Terlepas dari banyaknya penyebab terjadinya konflik, perbedaan latar belakang kedua belah pihak hingga terjadi konflik, perbedaan kepentingan diantara individu dalam kelompok/masyarakat yang kesemuanya saling terkait dalam realita sosial yang kompleks. Konflik bukanlah sesuatu yang harus dihindari, dianggap momok yang menakutkan dalam kehidupan berorganisasi melainkan harus dipandang sebagai dinamisator dalam setiap aktifitas organisasi itu sendiri, tanpa konflik organisasi akan mati dan dengan adanya konflik organisasi akan hidup dan berkembang.

Dibutuhkan suatu sinergi untuk menyelesaikan konflik dengan menjalankan ajaran Asta Brata, sehingga konflik yang terjadi dapat terselesaikan dengan baik dan membawa organisasi ke arah kemajuan. Jika dipaparkan lebih rinci dari bagian-bagian Asta Brata yang diterapkan dan bersinergi dengan konflik yang terjadi di dunia pendidikan dapat dijabarkan sebagai berikut:

1) Penerapan Indra Brata:

Seorang kepala sekolah yang tidak pernah peduli dengan kondisi guru-guru dan pegawainya, hanya berprinsip yang penting pekerjaan selesai, tidak peduli dengan kepentingan bawahannya (sudah makan atau belum, kondisi sehat atau sakit, dan sebagainya). Hal ini akan memicu terjadinya konflik misalnya ketidakpuasan guru dan pegawai mengakibatkan tugastugas dikerjakan dengan setengah hati sehingga hasilnya tidak maksimal. Oleh karena itu, dalam kasus ini diperlukan sikap seorang kepala sekolah seperti Dewa Indra yaitu seorang pemimpin dalam hal ini peduli dan memperjuangkan rakyatnya, jadi seorang kepala sekolah hendaknya selalu memperhatikan kondisi guru dan pegawainya serta memperjuangkan hakhak mereka sehingga dalam bekerja kinerjanya dapat lebih meningkat.

2) Penerapan Yama Brata

Konflik yang terjadi di sekolah seperti misalnya ketidakadilan pembagian jumlah jam mengajar guru, akan terkesan terjadi ketidakadilan atau pilih kasih. Dalam kasus ini seorang kepala sekolah harus mampu bersikap seperti Dewa Yama yaitu adil dengan memberikan pengertian kepada guru-guru atau alasan yang masuk akal kenapa terdapat perbedaan jumlah jam mengajar, sehingga konflik yang terjadi dapat dikelola dengan baik dan guru-guru dapat mematuhi dan menjalankan tugas-tugas yang diberikan.

3) Penerapan Surya Brata

Konflik yang terjadi di sekolah terkait penggunaan anggaran ataupun dana bantuan. Dalam hal ini seorang kepala sekolah harus mempunyai sifat seperti Dewa Surya bersikap terbuka dan transparan memberikan informasi yang benar terkait penggunaan anggaran tersebut sehingga konflik ataupun rumor yang terjadi bisa diselesaikan dan tidak ada lagi keragu-raguan dalam bekerja.

4) Penerapan Candra Brata

Ketidakramahan seorang kepala sekolah kepada guru-guru, pegawai dan siswa juga dapat menjadi pemicu konflik seperti komunikasi yang sering terganggu yang dapat mengakibatkan kesalahpahaman akan menghambat kinerja organisasi. Dalam kasus ini seorang kepala sekolah hendaknya berlaku seperti Dewa Candra (bulan) yaitu selalu dapat memperlihatkan wajah yang tenang dan berseri-seri dalam tugasnya sehari-hari, sehingga dengan demikian guru, pegawai, siswa yang dipimpinnya merasa yakin akan kebesaran jiwa pemimpinnya serta simpati dan penuh rasa hormat.

5) Penerapan Bayu Brata

Terjadi ketidakcocokan antara guru satu dengan guru yang lainnya karena suka dibandingbandingkan prestasinya. Hal ini dapat memicu terjadinya konflik antar guru tersebut. Disinilah peran kepala sekolah untuk menerapkan Bayu Brata dengan menjalin komunikasi melalui pertemuan formal (rapat) maupun informal dengan guru-guru dan pegawai. Hal-hal yang dibicarakan tidak hanya masalah pekerjaan tetapi seorang kepala sekolah perlu berada di 
tengah-tengah guru dan pegawainya untuk mengetahui keadaan atau kemauan dari bawahannya dengan tidak membanding-bandingkan satu dengan yang lainnya.

\section{6) Penerapan Kuwera Brata}

Terjadinya konflik di sekolah antara kepala sekolah dengan komite sekolah terkait penggunaan dana pembangunan gedung baru sekolah yang kurang dari anggaran semula. Untuk mencegah masalah ini kepala sekolah harus bertindak sesuai ajaran Kuwera Brata yaitu hendaknya bijaksana dalam mempergunakan dana, mampu mempergunakan uang sehemat mungkin, tanpa ada pemborosan, sehingga dengan demikian semua rencana pembangunan gedung sekolah dapat terwujud.

\section{7) Penerapan Baruna Brata}

Terjadinya konflik antar guru maupun siswa karena pemahaman yang kurang dari guru terkait dengan prinsip pembelajaran dalam jaringan (Daring). Ada guru yang hanya memberikan banyak tugas saja kepada siswanya, ada guru yang tetap ketat memberikan batas waktu terkait pengumpulan tugas/ujian, ada guru yang tiap pertemuannya selalu mengadakan tatap muka virtual. Hal ini tentunya akan membebani siswa dalam belajar, mengingat kemampuan siswa berbeda beda dalam ketersediaan sarana teknologi pembelajaran daring. Oleh karena itu diperlukan penerapan Baruna Brata oleh seorang kepala sekolah untuk memberikan wawasan/pengetahuan yang lebih luas dan mendalam terkait konsep pelaksanaan pembelajaran daring yang baik dan benar sehingga tidak memberatkan siswa dalam belajar.

\section{8) Penerapan Agni Brata}

Permasalahan yang terjadi ketika guru-guru di sekolah malas untuk mengurus kenaikan pangkatnya, hal ini akan berimbas pada kesejahteraan guru dan peringkat sekolah. Dalam kasus ini seorang kepala sekolah dapat menerapkan ajaran Agni Brata yaitu harus mampu memberikan semangat yang berkobar-kobar dengan memberikan strategi-strategi yang sekiranya dapat mempercepat proses kenaikan pangkat sehingga para guru termotivasi untuk mengurus kenaikan pangkatnya yang akan berimbas kepada reputasi lembaga.

\section{Simpulan dan Saran}

Berdasarkan hasil dan pembahasan yang telah dipaparkan sebelumnya, simpulan yang dapat diambil dari penelitian ini yaitu: Kepemimpinan berlandaskan ajaran Asta Brata dari sudut pandang teori konflik merupakan ajaran kepemimpinan dalam agama Hindu yang dapat digunakan sebagai peredam konflik yang terjadi. Dapat dikatakan demikian karena Asta Brata merupakan ajaran kepemimpinan yang mengajarkan sifat-sifat dari delapan dewa dalam agama Hindu. Seorang pemimpin dalam hal ini kepala sekolah seharusnya memiliki sifat kedewataan sehingga dapat lebih bijaksana dalam menjalankan kepemimpinannya di lingkungan sekolah. Dengan sifat kedewataan yang diterapkan diharapkan apa yang menjadi visi, misi dan tujuan sekolah dapat tercapai dengan mengelola konflik yang terjadinya ke arah yang positif. Konflik memang tidak dapat dihindari dalam suatu organisasi. Kemampuan menangani konflik oleh pimpinan dalam hal ini kepala sekolah yang terpenting adalah mengembangkan pengetahuan yang cukup dan sikap yang positif terhadap konflik, karena peran konflik tidak selalu negatif terhadap organisasi. Dengan penerapan ajaran Asta Brata, pimpinan diharapkan dapat cepat mengenal, mengidentifikasi dan mengukur besarnya konflik serta akibatnya dengan sikap positif sehingga apa yang menjadi tujuan sekolah dapat tercapai.

Saran yang ingin disampaikan berdasarkan simpulan ini yaitu bagi kepala sekolah agar dapat menerapkan filosofi Asta Brata ini dalam menjalankan kepemimpinan di sekolah masingmasing sehingga tercipta keharmonisan antar warga sekolah. Sedangkan bagi para peneliti lainnya disarankan dapat lebih menggali lagi nilai-nilai filosofi khususnya nilai kearifan lokal yang terkait kepemimpinan, sehingga semakin banyak konsep kepemimpinan yang relevan untuk diterapkan. Hal ini tentunya dapat memberikan dampak yang positif bagi kemajuan organisasi, khususnya lembaga pendidikan. 


\section{Daftar Rujukan}

Brata, T. (2011). Peran Kepemimpinan Dalam Mengendalikan Konflik. Jurnal Media Wahana Ekonomika, 7(4), 56-64. https://jurnal.univpgripalembang.ac.id/index.php/Ekonomika/article/download/4282/3956

Diharjo, S. M. (2019). Dinamika Perubahan Sosial dalam Teori Konflik. Jurnal Ilmu Komunikasi Dan Bisnis, 5(1), 1-17. http://jurnal.stiks-tarakanita.ac.id/index.php/JIK/article/view/259

Komara, E. (2019). Teori Sosiologi dan Antropologi (1st ed.). PT. Refika Aditama.

Manik, J. (2013). Kekuasaan Dan Kepemimpinan Sebagai Proses Sosial Dalam Bermasyarakat. Society, 1(1). Bangka Belitung University. https://www.neliti.com/publications/130355/

Maunah, B. (2015). Pendidikan Dalam Perspektif Struktural Konflik. Cendikia:Journal of Education and Teaching, 9(1), 71. https://doi.org/10.30957/cendekia.v9i1.53

Sidharta. (2010). Kepemimpinan Hindu Asta Brata dan Nasehat Sri Rama Lainnya. Paramitha.

Sudarmiati, N. (2020). Landasan Ajaran Asta Brata Dalam Kepemimpinan Kepala Sekolah Di SMA N 7 Luwu Timur. Widyalaya: Jurnal Ilmu Pendidikan, 1(2). http://jurnal.ekadanta.org/index.php/Widyalaya/article/view/96

Sugiyono. (2019). Metode Penelitian Pendidikan Pendekatan Kuantitatif, Kualitatif dan R\&D. Alfabeta.

Syamsul, H. (2017). Penerapan Kepemimpinan Kepala Sekolah Dalam Meningkatkan Kinerja Guru Pada Jenjang Sekolah Menengah Pertama (SMP). Idaarah: Jurnal Manajemen Pendidikan, 1(2), 275-289. https://doi.org/10.24252/idaarah.v1i2.4271

Tualeka, M. W. N. (2017). Teori Konflik Sosiologi Klasik Dan Modern. Al-Hikmah, 3(1), 32-48. http://journal.um-surabaya.ac.id/index.php/Ah/article/view/409

Usman, H. (2013). Manajemen: Teori, Praktik, dan Riset Pendidikan (4th ed.). Bumi Aksara. 